Check for updates

Cite this: RSC Adv., 2019, 9, 19940

\section{Immobilization of Lewis acidic ionic liquid on perlite nanoparticle surfaces as a highly efficient solid acid catalyst for the solvent-free synthesis of xanthene derivatives}

\begin{abstract}
L. Moradi (D) and M. Mirzaei
In this study, perlite nanoparticles were prepared through a simple method and then modified with Lewis acidic ionic liquid (perlite NP(alL/ $\mathrm{ZCl}_{4}$ ) through a two step procedure. The prepared solid acid catalyst was characterized by Fourier transform infrared spectroscopy (FTIR), scanning electron microscopy (SEM), X-ray diffraction (XRD), energy-dispersive X-ray spectroscopy (EDX) and thermo gravimetric analysis (TGA). Perlite NP(IIL/Z $\mathrm{rCl}_{4}$ was used as a new solid acid, reusable and green heterogeneous nanocatalyst for the one-pot synthesis of xanthene derivatives. Synthesis of xanthenes was performed under solvent free conditions using a catalytic amount $(0.005 \mathrm{~g}, 0.4 \mathrm{~mol} \%)$ of the prepared catalyst with simple work-up and high to excellent yield of products. The reusability and high efficiency of this catalyst makes this method attractive for large scale environment-friendly operations.
\end{abstract}

Received 3rd May 2019

Accepted 19th June 2019

DOI: $10.1039 / c 9 r a 03312 b$

rsc.li/rsc-advances
$15 \%), \mathrm{Na}_{2} \mathrm{O}(3-4 \%), \mathrm{K}_{2} \mathrm{O}(3-5 \%), \mathrm{Fe}_{2} \mathrm{O}_{3}(0.5-2 \%), \mathrm{MgO}(0.2-$ $0.7 \%)$ and $\mathrm{CaO}(0.5-1.5 \%) .{ }^{39,40}$ Because of its low density and relatively low price, many commercial applications for perlite have been developed in the construction and manufacturing fields. It is used in lightweight plasters, concrete, insulation and ceiling tiles. ${ }^{41}$ In horticulture, perlite can be used as a soil amendment or alone as a medium for hydroponics or starting cuttings. ${ }^{42}$ Small quantities of perlite are also used in foundries, cryogenic insulation and in ceramics as a clay additive. It is also used by the explosives industry. ${ }^{42}$ It was found to be an excellent support for immobilization of catalysts and biocatalysts such as enzymes for bioremediation and sensing applications. ${ }^{\mathbf{2 4 , 4 3 , 4 4}}$ To avoid of using the toxic organic solvents and due to the advantages of multicomponent reactions including low response time, high efficiency, clean work-up and easy purification, we have designed environmentally benign procedures for the one-pot synthesis of xanthene and naphthopyranopyrimidine derivatives under thermal and solvent free conditions using perlite NPS@IL/ $\mathrm{ZrCl}_{4}$ as a new efficient and reusable solid acid catalyst (Scheme 1).

\section{Results and discussion}

FT-IR spectra of perlite nanoparticles and perlite NPs@IL/ $\mathrm{ZrCl}_{4}$ were presented in Fig. 1 to prove the catalyst structure. FTIR of perlite nanoparticles (Fig. 1a), shows the broad band at $3438.09 \mathrm{~cm}^{-1}$, correspond to $\mathrm{O}-\mathrm{H}$ vibrations. Bands at 1013.52 and $789.08 \mathrm{~cm}^{-1}$ related to unsymmetrical and symmetrical $\mathrm{Si}-$ $\mathrm{O}-\mathrm{Si}$ vibrations, respectively. The $\mathrm{Si}-\mathrm{O}$ vibrations on perlite nanoparticles were appeared at $458.35 \mathrm{~cm}^{-1}$. In FTIR spectrum 


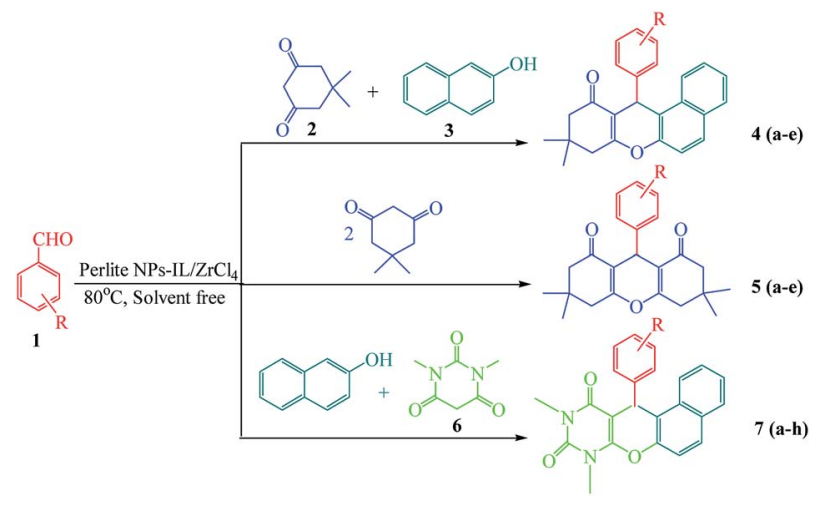

Scheme 1 Solvent free one-pot synthesis of three types of xanthene derivatives in the presence of perlite NPs@IL/ $\mathrm{ZrCl}_{4}$.

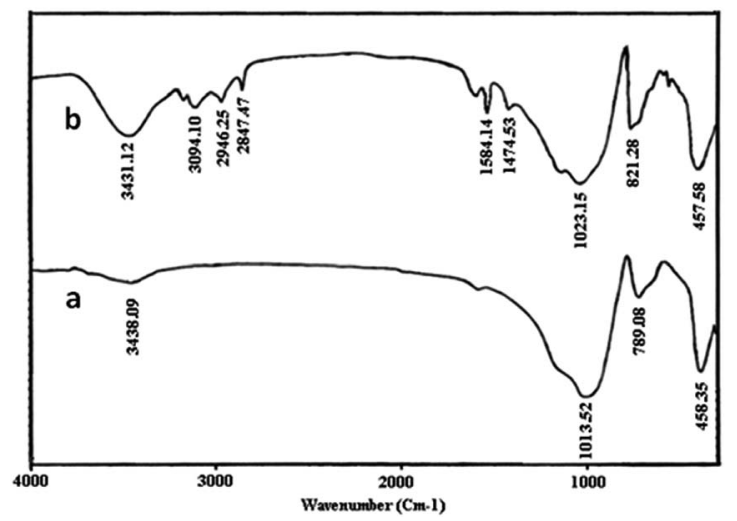

Fig. 1 FT-IR spectra of (a) perlite NPs and (b) perlite NPs@IL/ZrCl .

of perlite NPs@IL/ $/ \mathrm{ZrCl}_{4}$, the band at $3431.12 \mathrm{~cm}^{-1}$ corresponds to $\mathrm{O}-\mathrm{H}$ vibrations and stretching vibrations of $=\mathrm{CH}$ appeared at $3094.10 \mathrm{~cm}^{-1}$. Also the bands at 2946.25 and $2847.47 \mathrm{~cm}^{-1}$ are from $-\mathrm{CH}$ bond vibrations. Moreover, two bands at 1584.14 and $1474.53 \mathrm{~cm}^{-1}$ were existed from $\mathrm{C}=\mathrm{N}$ and $\mathrm{C}=\mathrm{C}$ vibrations, respectively. Stretching vibrations at 1023.15 and $821.28 \mathrm{~cm}^{-1}$ are related to unsymmetrical and symmetrical $\mathrm{Si}-\mathrm{O}-\mathrm{Si}$ vibrations. Finally, the $\mathrm{Si}-\mathrm{O}$ absorbance recorded at $457.58 \mathrm{~cm}^{-1}$.

TGA curve of perlite NPs@IL/ $/ \mathrm{ZCl}_{4}$ at the range of 25 to $800{ }^{\circ} \mathrm{C}$ is shown in Fig. 2. The weight loss at the range of 100 to

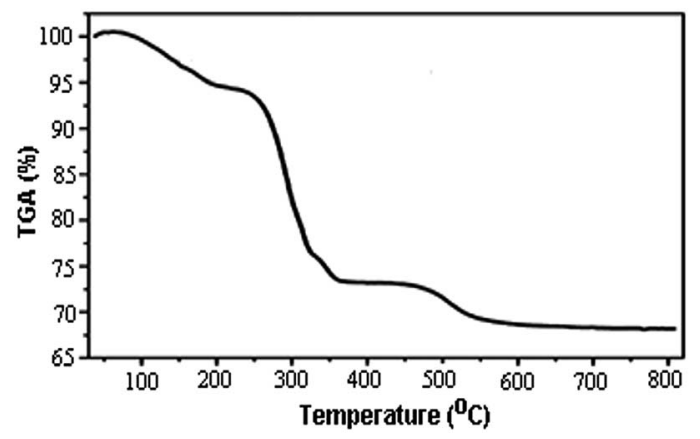

Fig. 2 TGA analysis of perlite NPs IL/ZrCl 4 .
$200{ }^{\circ} \mathrm{C}$ was only $5 \%$. This can be attributed to the removal of moisture from nanoparticle surfaces. A weight loss about $21 \%$ in the range of 300 to $350{ }^{\circ} \mathrm{C}$ is related to the separation of ionic liquid from the surface of catalyst. Finally, by removing the hydroxyl groups from perlite nanoparticle surfaces, a weight loss about $4 \%$ in the range of 480 to $520{ }^{\circ} \mathrm{C}$ is observed. Obtained results from TGA graph confirmed the chemical attachment of organic groups to the perlite NPs surfaces.

$\mathrm{X}$-ray diffraction analysis was used for investigating the structure of perlite nanoparticles and perlite NPs@IL/Z $\mathrm{ZrCl}_{4}$. The obtained diffractograms are displayed in Fig. 3. As shown in this Figure, XRD patterns of primary and modified perlite nanoparticles exhibit the same characteristic peaks which shows that the peaks and relative intensities match well with the X-ray diffraction pattern of amorphous particles and the structure of the primary perlite NPS preserved in the prepared catalyst. These graphs also show that the presence of organic species has no effect on the structure of perlite NPs. The peaks related to $\mathrm{ZrCl}_{4}$ are recorded at $2 \theta=30,33,50.5$ and $60^{\circ}$. In the XRD pattern of perlite NPs@IL/ $\mathrm{ZrCl}_{4}$, the peaks of $2 \theta=33$ and $50.5^{\circ}$ are distinguishable and two other peaks are covered by other broad peaks.

The scanning electron microscope (SEM) images of the perlite NPs and perlite NPs@IL/ $/ \mathrm{ZCl}_{4}$ were displayed in Fig. 4(a and $b$ ). These images clearly show the nanosize structure of perlite NPs and modified sample. As can be seen from Fig. 4b, the morphology of the perlite NPs@IL/ $\mathrm{ZrCl}_{4}$ was quite similar to the raw nanoparticles and there are no changes in nanoparticle morphology after modification process.

The composition of perlite nanoparticles and synthesized catalyst was investigated by energy-dispersive X-ray spectroscopy (EDX). Results clearly confirmed the existence of $\mathrm{Zr}, \mathrm{Cl}$ and $\mathrm{N}$ elements in the prepared catalyst structure (Fig. 5) and consequently proved that ionic liquid and $\mathrm{ZrCl}_{4}$ were attached successfully to the perlite nanoparticle surfaces.

As can be seen, the $\mathrm{Zr}$ and $\mathrm{N}$ content was $6.9 \%$ and $2.5 \%$ respectively. It concluded that the percentage of ionic liquid immobilized on perlite surfaces was about 1.25\%. Further amount of $\mathrm{Zr}$ demonstrated the chelating of $\mathrm{Zr}$ to $\mathrm{OH}$ groups

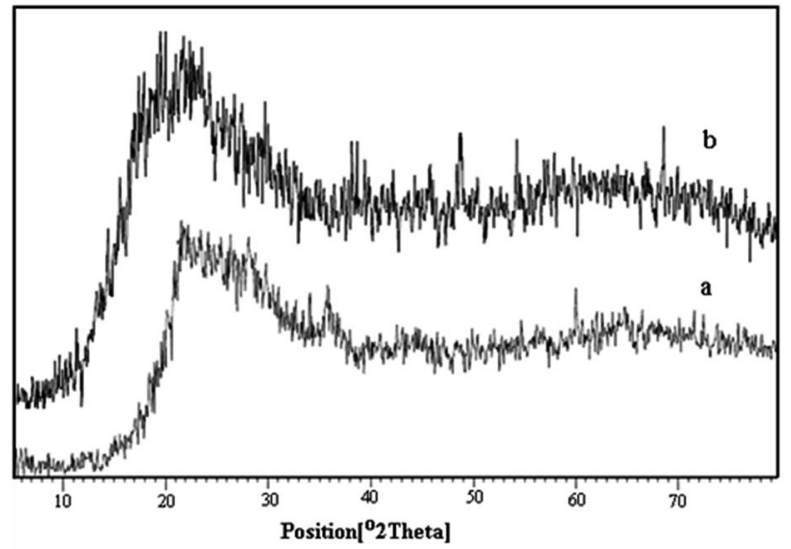

Fig. 3 X-ray diffraction (XRD) pattern of (a) perlite and (b) perlite-IL/ $\mathrm{ZrCl}_{4}$ nanoparticles. 

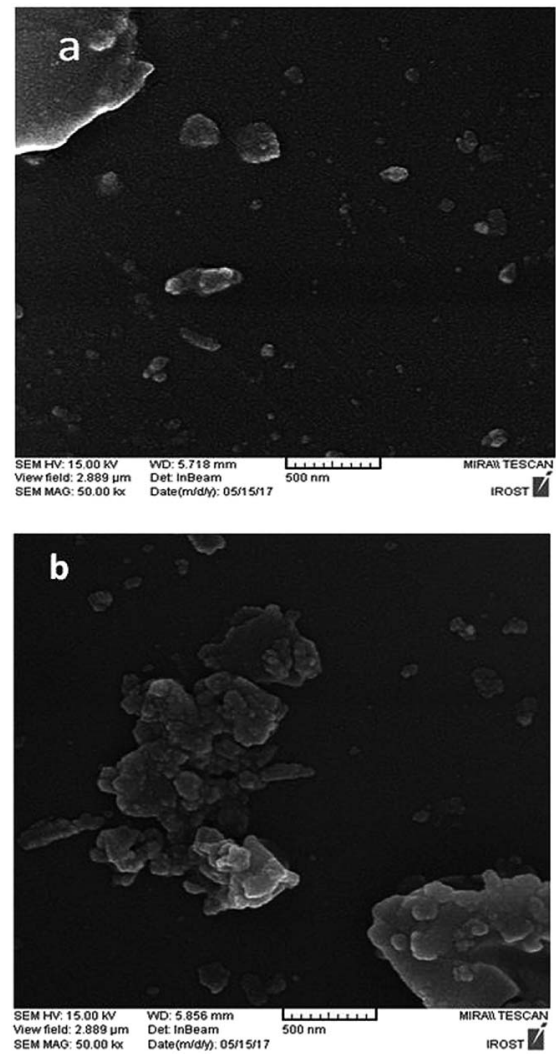

Fig. 4 SEM photographs of (a) perlite NPs and (b) perlite NPs@IL/ZrCl nanoparticles.

existed on the perlite surfaces (addition to be as zwitterion for imidazolium ion). Furthermore, the mol\% of catalyst based on $\mathrm{Zr}$ ration was about $0.4 \mathrm{~mol} \%$.

After the preparation and characterization of catalyst, reaction conditions including the amount of catalyst and temperature were optimized. Firstly, optimum amount of catalyst was determined using the reaction between dimedone $(2 \mathrm{mmol})$ and 3-nitrobenzaldehyde $(1 \mathrm{mmol})$ in the presence of various amounts of catalyst at $80^{\circ} \mathrm{C}$. Results in Table 1 show that the best yield of product was obtained in the presence of $0.005 \mathrm{~g}$ (0.4 mol\%) of catalyst (entry 2$)$; also when the reaction was carried out in the absence of catalyst, the yield of product was only $5 \%$ after $100 \mathrm{~min}$ (entry 5).

For evaluation the temperature effect on the yield of product, the model reaction was done in the presence of $0.005 \mathrm{~g}$ $(0.4 \mathrm{~mol} \%)$ of catalyst at different temperatures (Table 2). Obtained results show that $80{ }^{\circ} \mathrm{C}$ was the best temperature (entry 3). Furthermore, the yield of product at $100{ }^{\circ} \mathrm{C}$ was decreased due to decomposition of products after 100 min (entry 5).

After the determination of optimized conditions, appraisal of the catalyst efficiency was estimated using the reaction of a variety of aryl aldehydes, 2-naphthol and 1,3-dicarbonyl compounds such as dimedone and barbituric acid for preparation of xanthene derivatives in the presence of catalytic amount of perlite NPs@IL/ZrCl $\mathrm{ZrC}_{4}$. Obtained results in Table 3 show that aldehydes bearing electron withdrawing groups lead
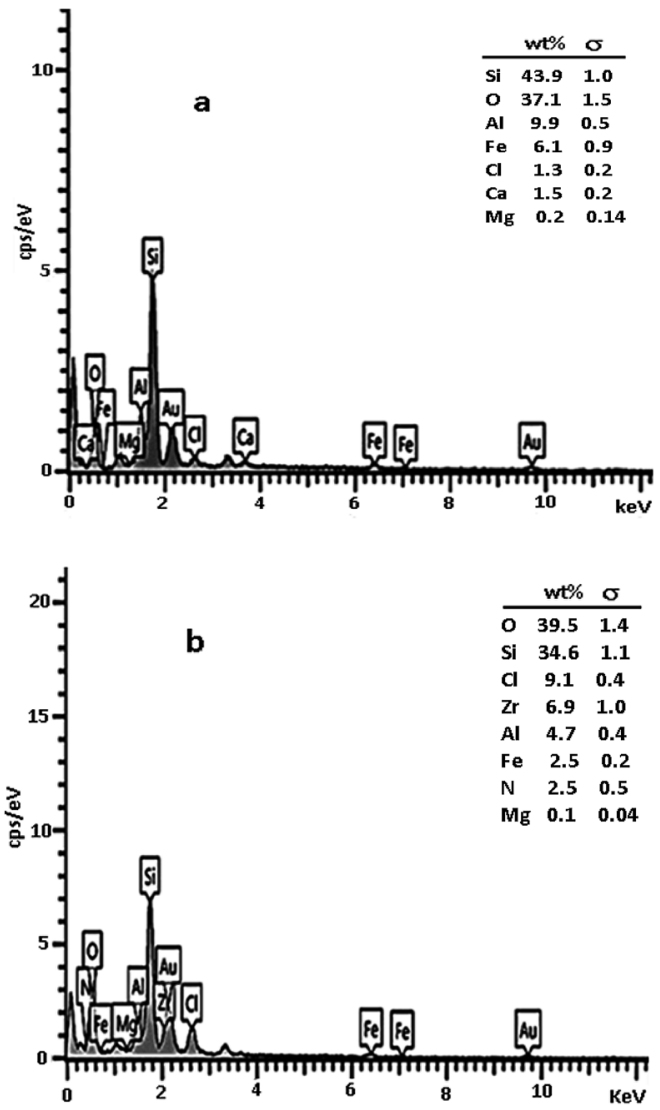

Fig. 5 EDX of perlite NPs (a) and perlite NPS@IL/ZrCl 4 (b).

to products with higher yields after shorter times. Also in case of aldehydes with electron donating groups, it was observed that yield of reaction was lower after longer times.

Further study was done using the reaction of terephthaldehyde with $2 \mathrm{mmol}$ of dimedone (2) and $2 \mathrm{mmol}$ of 2naphthol (3) for the preparation of 4e. Symmetric dimer product was prepared with the reaction of terephthaldehyde with $4 \mathrm{mmol}$ of dimedone (2) for preparation of $\mathbf{5 e}$ (Scheme 2). The

Table 1 Effects of catalyst amounts on yield of $5 a^{a}$

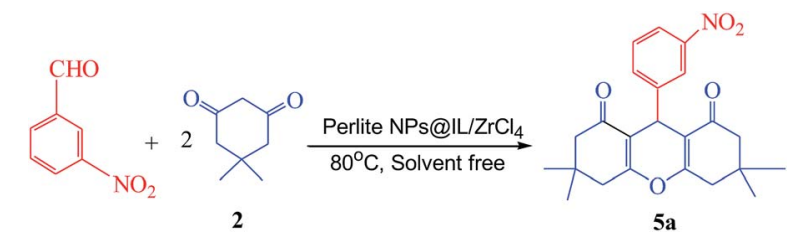

\begin{tabular}{llll}
\hline Entry & Catalyst $(\mathrm{g})$ & Time $(\mathrm{min})$ & Yield $(\%)$ \\
\hline 1 & 0.003 & 140 & 85 \\
2 & 0.005 & 100 & 92 \\
3 & 0.008 & 100 & 92 \\
4 & 0.01 & 85 & 92 \\
5 & - & 100 & 5
\end{tabular}

${ }^{a}$ Isolated yield. 
Table 2 Optimization of reaction temperature ${ }^{a}$

\begin{tabular}{llll}
\hline Entry & $T\left({ }^{\circ} \mathrm{C}\right)$ & Time $(\mathrm{min})$ & Yield $(\%)$ \\
\hline 1 & 60 & 180 & 58 \\
2 & 70 & 130 & 75 \\
3 & 80 & 100 & 92 \\
4 & 90 & 100 & 92 \\
5 & 100 & 100 & 88
\end{tabular}

${ }^{a}$ Dimedone (2 mmol), 3-nitrobenzaldehyde $(1 \mathrm{mmol})$ in the presence of $0.005 \mathrm{~g}(0.4 \mathrm{~mol} \%)$ of catalyst.

Table 3 One pot synthesis of xanthene derivatives in the presence of perlite NPs@IL/ZrCl 4 at $80{ }^{\circ} \mathrm{C}$ under solvent free conditions

\begin{tabular}{llllll}
\hline Entry & R & Product & Time (min) & Yield (\%) & MP $\left({ }^{\circ} \mathrm{C}\right)$ \\
\hline 1 & $4-\mathrm{CH}_{3}$ & $\mathbf{4 a}$ & 110 & 91 & $206-208$ (ref. 45) \\
2 & $4-\mathrm{OH}$ & $\mathbf{4 b}$ & 120 & 89 & $215-217$ (ref. 45) \\
3 & $4-\mathrm{OCH}_{3}$ & $\mathbf{4 c}$ & 115 & 88 & $204-206$ (ref. 45) \\
4 & $2-\mathrm{Cl}$ & $\mathbf{4 d}$ & 113 & 91 & $178-180$ (ref. 45) \\
$5^{a}$ & $4-\mathrm{CHO}$ & $\mathbf{4 e}$ & 120 & 91 & $306-308$ (ref. 45) \\
6 & $3-\mathrm{NO}_{2}$ & $\mathbf{5 a}$ & 100 & 92 & $171-173$ (ref. 45) \\
7 & $2,4-\mathrm{Cl}_{2}$ & $\mathbf{5 b}$ & 115 & 89 & $245-247$ (ref. 45) \\
8 & $4-\mathrm{CH}_{3}$ & $\mathbf{5 c}$ & 120 & 89 & $240-242$ (ref. 45) \\
9 & $2-\mathrm{Cl}$ & $\mathbf{5 d}$ & 112 & 91 & $225-227$ (ref. 45) \\
$10^{b}$ & $4-\mathrm{CHO}$ & $\mathbf{5 e}$ & 120 & 91 & $228-230$ (ref. 20) \\
11 & $4-\mathrm{OH}^{2}$ & $\mathbf{7 a}$ & 115 & 91 & $286-288$ (ref. 46) \\
12 & $2,4-\mathrm{Cl}_{2}$ & $\mathbf{7 b}$ & 113 & 88 & $263-265$ (ref. 46) \\
13 & $4-\mathrm{NO}_{2}$ & $\mathbf{7 c}$ & 90 & 94 & $286-288$ (ref. 46) \\
14 & $4-\mathrm{CH}_{3}$ & $\mathbf{7 d}$ & 130 & 88 & $195-197$ (ref. 46) \\
15 & $4-\mathrm{OCH}_{3}$ & $\mathbf{7 e}$ & 133 & 83 & $292-294$ (ref. 46) \\
16 & $2-\mathrm{OH}^{2}$ & $\mathbf{7 f}$ & 120 & 90 & $288-290$ (ref. 47) \\
17 & $3-\mathrm{OCH}_{3}$ & $\mathbf{7 g}$ & 105 & 92 & $283-285$ (ref. 48)
\end{tabular}

${ }^{a} 2$ (2 mmol), 3 ( $\left.2 \mathrm{mmol}\right)$, terephthaldehyde $(1 \mathrm{mmol}) .{ }^{b}$ Dimedone (4 $\mathrm{mmol})$, aryl aldehyde (1 mmol).

yield of products was excellent and the spectroscopic data of these products demonstrated the structure of prepared compounds.

In continue, the efficiency of prepared catalyst was compared with some of other reported catalyst applied for the synthesis of 4c, 5a and 7c (as examples of three types of synthesized xanthene derivatives). The results are summarized in Table 4 . As shown in this table, best yields were obtained using $0.005 \mathrm{~g}$

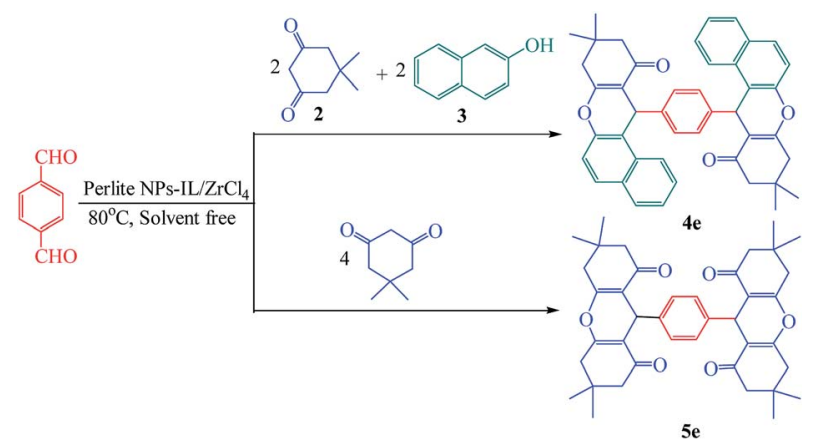

Scheme 2 Preparation of dimeric xanthenes.
(0.4 mol\%) of perlite-NPs@IL/ $/ \mathrm{ZrCl}_{4}$ at $80{ }^{\circ} \mathrm{C}$ in the absence of solvent (Entry 6, 18 and 27). Catalyst amount in presented method is less than most of catalysts depicted in Table 4 demonstrated the high efficiency of solid acid catalyst.

On the other hand, in most reaction conditions (16 cases) the temperature is higher than $80^{\circ} \mathrm{C}$ (applied temperature in presented method) and the yield of products is lower. As a result, Lewis acidic ionic liquid supported catalyst is more active than others in term of time, catalyst amount and temperature. In fact, $\mathrm{Zr}$ atoms (as Lewis acid sites) loaded in catalyst surfaces, can be activated the reactants (as shown in reaction mechanism) and catalyzed the solvent-free synthesis of xanthenes. Results collected in Table 4 shown that prepared catalyst improved the yield of products compare with other catalysts.

Furthermore, easy available and very low cost material of catalyst support (perlite), facile procedure for preparation of perlite nanoparticles as well as easy functionalization process, reusability and easy work up are some of the advantageous of proposed method. As can be seen in Table 4, most of catalysts are expensive, homogeneous, toxic and without facile availability.

Consequently, presented method has proved to be very effective, green, eco-friendly, safe and easy to operate and also the scale up of this method is easy.

Suggested mechanism for the synthesis of xanthene derivatives is shown in Scheme 3. As can be seen, in the initial step, Lewis acidic ionic liquid catalyzed the conversion of keto to enol form of 1,3 dicarbonyl; on the other hand, catalyst activated the carbonyl group of aldehyde and the nucleophilic addition of 1,3 dicarbonyl compound to activated aldehyde lead to formation of (I). Removal of $\mathrm{H}_{2} \mathrm{O}$ and nucleophilic addition of second mole of 1,3 dicarbonyl compound to I, created the intermediate II. Finally, cyclization and $\mathrm{H}_{2} \mathrm{O}$ removal from (II), give subsequent xanthene.

One of the outstanding advantages of the catalysts is their reusability and stability which makes them valuable for commercial applications. Study on the reusability of prepared catalyst was done using model reaction. After completion of the reaction, the catalyst was separated. The recovered catalyst was washed with chloroform $(3 \times 5 \mathrm{ml})$ and dried to use for the next run in current reaction under equal conditions. It was found that the catalyst could be reused for four times without considerable loss of its activity (Fig. 6).

The characterization of recovered catalyst by FTIR and SEM methods was shown in Fig. 7. As can be seen, no changes were occurred on morphology and particle size of recycled catalyst; also, the main peaks are identical in both of the fresh and recycled catalyst. Consequently, the prepared catalyst has high stability and high efficiency in solvent-free synthesis of xanthenes.

\section{Experimental}

\section{Materials and apparatus}

Chemicals such as dimedone, $N, N$-dimethylbarbituric acid, aldehyde derivatives, 2-naphthol, methyl imidazole, perlite nanoparticles, chloropropyltriethoxysilane, zirconium tetrachloride, 
Table 4 Compression between the efficiency of perlite-NPsalL/ZrCl 4 and some of other catalysts in synthesis of xanthenes and naphthopyranopyrimidines ${ }^{a}$

\begin{tabular}{|c|c|c|c|c|c|}
\hline Entry & Catalyst & Time & Yield (\%) & $T\left({ }^{\circ} \mathrm{C}\right)$ & Ref. \\
\hline 1 & {$\left[n-\mathrm{Pr}_{2} \mathrm{NH}_{2}\right]\left[\mathrm{HSO}_{4}\right](50 \mathrm{~mol} \%)$} & $15 \mathrm{~min}$ & 82 & 80 & 49 \\
\hline 2 & $\operatorname{BBSIC}^{b}(2 \mathrm{ml})$ & $10 \mathrm{~min}$ & 80 & 50 & 50 \\
\hline 4 & $\mathrm{InCl}_{3}(30 \mathrm{~mol} \%)$ & $45 \mathrm{~min}$ & 76 & 120 & 51 \\
\hline 5 & $\operatorname{TCCA}^{c}(5 \mathrm{~mol} \%)$ & $40 \mathrm{~min}$ & 78 & 110 & 45 \\
\hline 6 & Perlite@Il/ $/ \mathrm{ZCl}_{4}(0.005 \mathrm{~g}, 0.4 \mathrm{~mol} \%)$ & $115 \min$ & 88 & 80 & - \\
\hline 9 & [CMMIM]Cl, sonication (0.2 g) & $1 \mathrm{~h}$ & 87 & $\mathrm{rt}$ & 54 \\
\hline 10 & $\mathrm{Co}\left(\mathrm{HSO}_{4}\right)_{2}(0.025 \mathrm{~g})$ & $4 \mathrm{~h}$ & 80 & 100 & 55 \\
\hline 11 & Nafion-H $(0.485 \mathrm{~g})$ & $12 \mathrm{~h}$ & 75 & 125 & 56 \\
\hline 12 & Choline peroxydisulfate $(2 \mathrm{mmol})$ & $5 \mathrm{~min}$ & 88 & 105 & 57 \\
\hline 13 & TCCA $(5 \mathrm{~mol} \%)$ & $20 \mathrm{~min}$ & 88 & 110 & 45 \\
\hline 14 & $\mathrm{TMGT}^{d}(50 \mathrm{mmol}) / \mathrm{TFA}(60 \mathrm{mmol})$ & $25 \mathrm{~min}$ & 92 & 75 & 58 \\
\hline 19 & $\mathrm{ZrOCl}_{2} /$ nano $\mathrm{TiO}_{2}(3 \mathrm{~mol} \%)$ & $25 \min$ & 85 & 100 & 48 \\
\hline 20 & Heteropolyacid (5 mol\%) & $24 \mathrm{~min}$ & 90 & 100 & 62 \\
\hline 21 & $\mathrm{H}_{3} \mathrm{PO}_{4} / \mathrm{Al}_{2} \mathrm{O}_{3}(0.1 \mathrm{~g} / 50 \% \mathrm{w} / \mathrm{w})$ & $50 \mathrm{~min}$ & 87 & 120 & 31 \\
\hline 22 & $\mathrm{I}_{2}(10 \mathrm{~mol} \%)$ & $55 \mathrm{~min}$ & 86 & 120 & 63 \\
\hline 23 & $\mathrm{InCl}_{3}(35 \mathrm{~mol} \%)$ & $25 \mathrm{~min}$ & 78 & 120 & 51 \\
\hline 24 & $\mathrm{P}_{2} \mathrm{O}_{5}(20 \mathrm{~mol} \%)$ & $80 \mathrm{~min}$ & 58 & 120 & 51 \\
\hline 25 & $\mathrm{SiO}_{2} @ \mathrm{HClO}_{4}(3 \mathrm{~mol} \%)$ & $1.5 \mathrm{~h}$ & 94 & 125 & 64 \\
\hline 26 & Perlite@IL/ZrCl ${ }_{4}(0.005$ g, 0.4 mol\%) & $90 \mathrm{~min}$ & 94 & 80 & - \\
\hline
\end{tabular}

${ }^{a}$ Entries 1-6 for solvent free preparation of 4c, 7-17 for preparation of 5a and 18-26 for 7c. ${ }^{b}$ 1,10-Butylenebis(3-sulfo-3H-imidazol-1-ium) chloride. ${ }^{c}$ Trichloroisocyanuric acid. ${ }^{d} 1,1,3,3-N, N, N^{\prime}, N^{\prime}$-Tetramethylguanidinium trifluoroacetate.

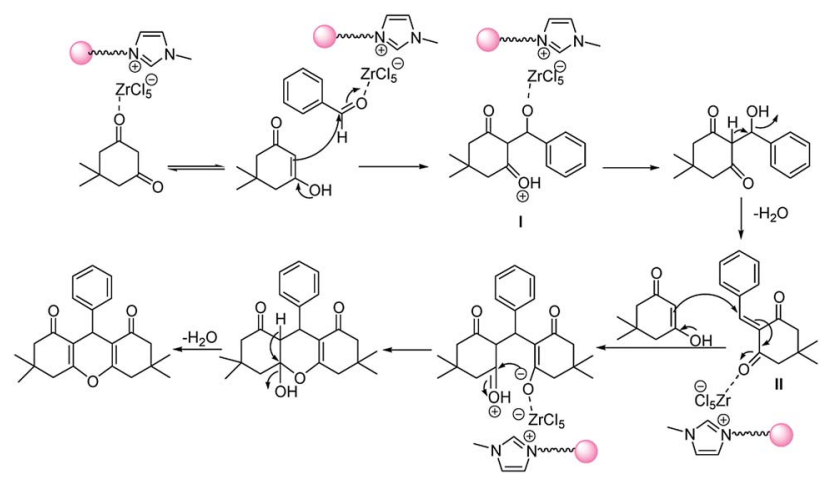

Scheme 3 Suggested mechanism for the one-pot synthesis of xanthene derivatives in the presence of perlite $\mathrm{NPs}\left(\mathrm{alL} / \mathrm{ZrCl}_{4}\right.$ nanoparticles.

methanol, organic solvents and hydrochloric acid were purchased from Fluka, Merck and Aldrich chemical companies. All of products were characterized by their spectral data. ${ }^{1} \mathrm{H}$ NMR spectra were recorded on a Avance BRUKER (DRX - $400 \mathrm{MHz}$ ) in $\mathrm{CDCl}_{3}$ or DMSO- $\mathrm{d}_{6}$ as solvent. FTIR spectra were determined on a Nicolet Magna series FTIR 550 spectrometer using KBr pellets. Thin layer chromatography (TLC) on commercial aluminium-backed plates of silica gel $60 \mathrm{~F}_{254}$ was used to monitor the progress of the reactions. Thermo gravimetric curve of perlite NPs@IL/ $\mathrm{ZrCl}_{4}$ were

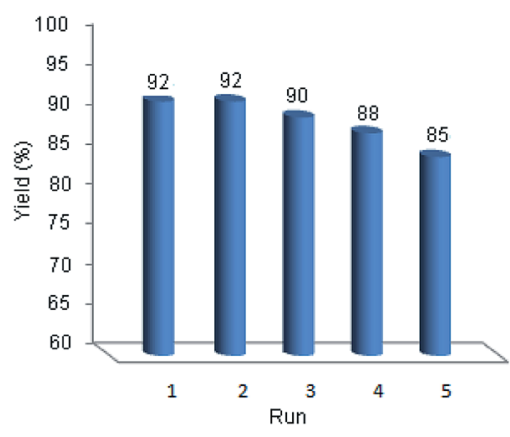

Fig. 6 Reusability of perlite NPsall// $\mathrm{ZrCl}_{4}$.

obtained from a STA503 analyzer. XRD patterns were collected on a Philips Xpert MPD diffractometer equipped with a $\mathrm{Cu} \mathrm{K} \alpha$ anode $(\lambda=1.54 \AA)$ in the $2 \theta$ range from 10 to $80^{\circ}$. Morphology of perlite NPs and catalyst, were analyzed by SEM using a MIRA/TESCAN with accelerating voltage of $120 \mathrm{kV}$.

\section{Preparation of perlite nanoparticles}

To make perlite from a crystalline to nanosize structure, $5 \mathrm{~g}$ of perlite was heated in $500{ }^{\circ} \mathrm{C}$ for 1 hour. Then $\mathrm{HCl}(150 \mathrm{ml}, 2 \mathrm{M})$ was added and refluxed for 24 hours. After that, the mixture was filtered, washed and $\mathrm{pH}$ was controlled to neutralize. Finally, 

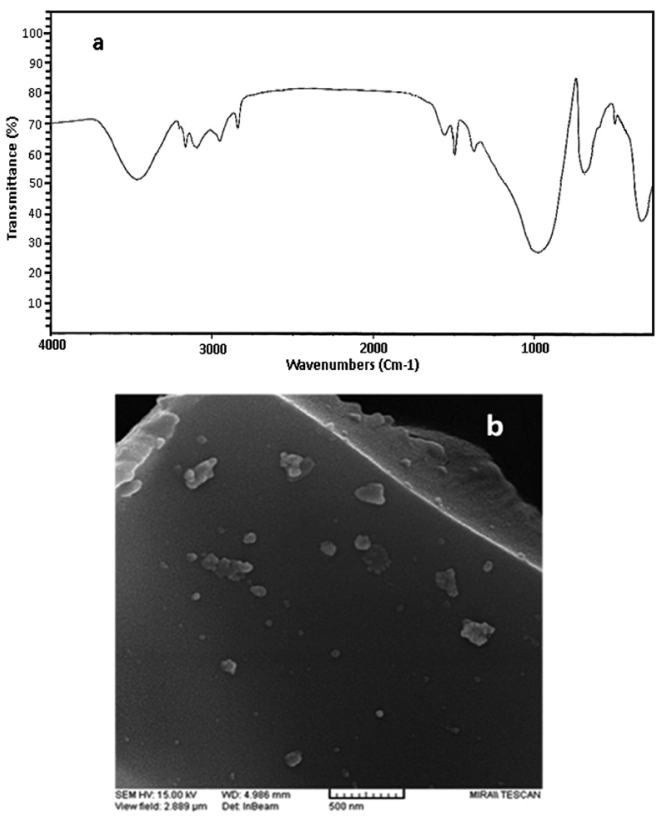

Fig. 7 FTIR (a) and SEM image (b) of recovered catalyst.

the precipitate was dried in $100{ }^{\circ} \mathrm{C}$ for 4 hours and then calcinated in $700{ }^{\circ} \mathrm{C}$ for 2 hours $^{23}$ (Scheme 4).

\section{Preparation of perlite NPs@IL/ $\mathbf{Z r C l}_{4}$}

In first step for preparation of catalyst, 1-(3-triethoxysilyl)propyl-3-methylimidazolium chloride $(\mathrm{Si}[\mathrm{pmim}] \mathrm{Cl})$ was synthesized according to Kumar method. ${ }^{65}$ A mixture of methyl imidazole (1 mmol) and 3-chloropropyltriethoxysilane (1 mmol) was refluxed in $5 \mathrm{ml}$ anhydrous toluene for 2 hours under $\mathrm{N}_{2}$ atmosphere. After the reaction time, obtained viscous ionic liquid was extracted by diethyl ether. In order to attach the ionic liquid to perlite nanoparticle surfaces, $1 \mathrm{~g}$ of perlite nanoparticles was added to $0.6 \mathrm{~g}$ of $\mathrm{Si}[\mathrm{pmim}] \mathrm{Cl}$ and stirred for 16 hours at $90{ }^{\circ} \mathrm{C}$. After the time, the mixture was washed with $10 \mathrm{ml}$ of boiling dichloromethane and dried. Then, $0.7 \mathrm{~g} \mathrm{Z \textrm {ZCl } _ { 4 }}$ dissolved in anhydrous toluene was added to obtained precipitate and stirred at room temperature for 12 hours. Finally,

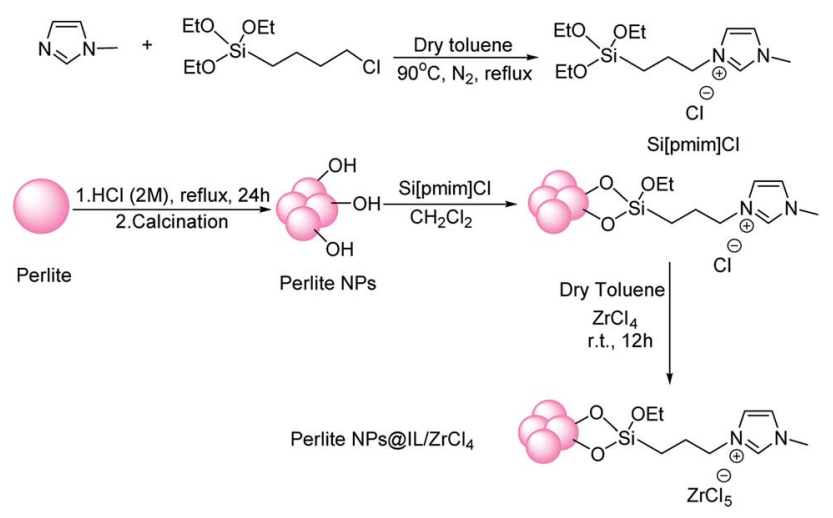

Scheme 4 Preparation of perlite NPsalL/ $\mathrm{ZrCl}_{4}$. prepared catalyst was dried at $80{ }^{\circ} \mathrm{C}$ and characterized by FT-IR, XRD, SEM, EDX and TGA techniques (Scheme 2).

\section{General procedure for the preparation of xanthene derivatives}

In order to achieve satisfactory results, in a general procedure, a mixture of $1 \mathrm{mmol}$ benzaldehyde derivative, $2 \mathrm{mmol}$ dimedone or (1 mmol 2-naphthol and $1 \mathrm{mmol}$ dimedone) in the presence of optimized amount of perlite@IL/ $\mathrm{ZrCl}_{4}$ nanoparticles $(0.005 \mathrm{~g}, 0.4 \mathrm{~mol} \%)$ was stirred for adequate times under conventional heating conditions at $80{ }^{\circ} \mathrm{C}$. After completion of the reaction, the mixture was resolved in hot ethanol and catalyst was separated by simple filtration. The crude product was obtained after evaporation and for further purification, recrystallized from ethanol. In case of naphthopyranopyrimidines, a mixture of $1 \mathrm{mmol}$ benzaldehyde derivative, $1 \mathrm{mmol}$ dimedone and $1 \mathrm{mmol} N, N$-dimethylbarbituric acid was stirred in the presence of $0.005 \mathrm{~g},(0.4 \mathrm{~mol} \%)$ of catalyst at $80{ }^{\circ} \mathrm{C}$. Separation and purification of reaction products was done according to xanthene route.

\section{Spectral data}

9,9-Dimethyl-12-(4-methylphenyl)-8,9,10,12-tetrahydrobenzo[a] xanthene-11-one (4a). White solid. Mp: 205-207 ${ }^{\circ} \mathrm{C} . \bar{\nu}_{\max }(\mathrm{KBr}) /$ $\mathrm{cm}^{-1}$ : 3015 (=C-H), $2958(-\mathrm{C}-\mathrm{H}), 1667(\mathrm{C}=\mathrm{O}), 1596-1417(\mathrm{C}=\mathrm{C})$, $1374\left(\mathrm{CH}_{3}\right.$, bending), 1300-1000 (C-O), 831 (= $\mathrm{C}-\mathrm{H}$ bending OOP of para disubstituted phenyl ring). ${ }^{1} \mathrm{H}$ NMR $\left(\right.$ DMSO- $\left._{6}\right) / \mathrm{ppm}: \delta_{\mathrm{H}}=8.01$ $\left(1 \mathrm{H}, \mathrm{d},{ }^{3} \mathrm{~J}_{\mathrm{HH}}=7.6 \mathrm{~Hz}, \mathrm{Ar}-\mathrm{H}\right), 7.49\left(2 \mathrm{H}, \mathrm{d},{ }^{3} J_{\mathrm{HH}}=8.4 \mathrm{~Hz}, \mathrm{Ar}-\mathrm{H}\right), 7.55-$ $7.42(3 \mathrm{H}, \mathrm{m}, \mathrm{Ar}-\mathrm{H}), 7.15\left(2 \mathrm{H}, \mathrm{d},{ }^{3} \mathrm{~J}_{\mathrm{HH}}=8.0 \mathrm{~Hz}, \mathrm{Ar}-\mathrm{H}\right), 6.96(2 \mathrm{H}, \mathrm{d}$, $\left.{ }^{3} \mathrm{~J}_{\mathrm{HH}}=8.0 \mathrm{~Hz}, \mathrm{Ar}-\mathrm{H}\right), 5.50(1 \mathrm{H}, \mathrm{s}, \mathrm{CH}), 2.56\left(2 \mathrm{H}, \mathrm{d},{ }^{2} \mathrm{~J}_{\mathrm{HH}}=17.6 \mathrm{~Hz}\right.$, $\left.\mathrm{CH}_{2} \mathrm{C}=\mathrm{O}\right), 2.32\left(2 \mathrm{H}, \mathrm{d},{ }^{2} J_{\mathrm{HH}}=16.4 \mathrm{~Hz}, \mathrm{CH}_{2}\right), 2.12\left(3 \mathrm{H}, \mathrm{s}, \mathrm{CH}_{3}\right), 1.05$ $\left(3 \mathrm{H}, \mathrm{s}, \mathrm{CH}_{3}\right), 0.88\left(3 \mathrm{H}, \mathrm{s}, \mathrm{CH}_{3}\right)$.

9,9-Dimethyl-12-(4-hydroxyphenyl)-8,9,10,12-tetrahydrobenzo[a] xanthene-11-one (4b). Pale yellow solid. Mp: $215-217^{\circ} \mathrm{C} . \bar{\nu}_{\max }(\mathrm{KBr}) /$ $\mathrm{cm}^{-1}$ : $3309(\mathrm{O}-\mathrm{H}), 3050(=\mathrm{C}-\mathrm{H}), 1717(\mathrm{C}=\mathrm{O}), 1642-1400(\mathrm{C}=\mathrm{C})$, $1366\left(\mathrm{CH}_{3}\right.$, bending), 1251 ( $\left.\mathrm{Ar}-\mathrm{O}\right), 1300-1000(\mathrm{C}-\mathrm{O}), 850(=\mathrm{C}-\mathrm{H}$ bending OOP of para disubstituted phenyl ring). ${ }^{1} \mathrm{H}$ NMR (DMSO$\left.\mathrm{d}_{6}\right) / \mathrm{ppm}: \delta_{\mathrm{H}}=9.20(1 \mathrm{H}, \mathrm{s}, \mathrm{OH}), 8.12\left(1 \mathrm{H}, \mathrm{d},{ }^{3} J_{\mathrm{HH}}=9.2 \mathrm{~Hz}, \mathrm{Ar}-\mathrm{H}\right)$, $7.88\left(2 \mathrm{H}, \mathrm{t},{ }^{3} \mathrm{~J}_{\mathrm{HH}}=9.2 \mathrm{~Hz}, \mathrm{Ar}-\mathrm{H}\right), 7.44-7.32(3 \mathrm{H}, \mathrm{m}, \mathrm{Ar}-\mathrm{H}), 7.26(2 \mathrm{H}$, $\left.\mathrm{d},{ }^{3} \mathrm{~J}_{\mathrm{HH}}=8.0 \mathrm{~Hz}, \mathrm{Ar}-\mathrm{H}\right), 6.65\left(2 \mathrm{H}, \mathrm{d},{ }^{3} J_{\mathrm{HH}}=8.0 \mathrm{~Hz}, \mathrm{Ar}-\mathrm{H}\right), 5.63$ $(1 \mathrm{H}, \mathrm{s}, \mathrm{CH}), 2.67\left(2 \mathrm{H}, \mathrm{d},{ }^{2} J_{\mathrm{HH}}=16.4 \mathrm{~Hz}, \mathrm{CH}_{2} \mathrm{C}=\mathrm{O}\right), 2.32\left(1 \mathrm{H}, \mathrm{d},{ }^{2} J_{\mathrm{HH}}\right.$ $\left.=16.0 \mathrm{~Hz}, \mathrm{CH}_{2}\right), 2.10\left(1 \mathrm{H}, \mathrm{d},{ }^{2} J_{\mathrm{HH}}=16.0 \mathrm{~Hz}, \mathrm{CH}_{2}\right), 1.05\left(3 \mathrm{H}, \mathrm{s}, \mathrm{CH}_{3}\right)$, $0.88\left(3 \mathrm{H}, \mathrm{s}, \mathrm{CH}_{3}\right)$.

9,9-Dimethyl-12-(4-methoxyphenyl)-8,9,10,12-tetrahydrobenzo[a] xanthene-11-one (4c). White solid. Mp: 204-206 ${ }^{\circ} \mathrm{C} . \bar{\nu}_{\max }(\mathrm{KBr}) /$ $\mathrm{cm}^{-1}$ : 3015 (=C-H), $2955(-\mathrm{C}-\mathrm{H}), 1648(\mathrm{C}=\mathrm{O}), 1597-1462(\mathrm{C}=\mathrm{C})$, $1377\left(\mathrm{CH}_{3}\right.$, bending), 1300-1000 (C-O), 831 (= $\mathrm{C}-\mathrm{H}$ bending OOP of para disubstituted phenyl ring). ${ }^{1} \mathrm{H}$ NMR $\left(\mathrm{DMSO}_{6}\right) / \mathrm{ppm}: \delta_{\mathrm{H}}=8.05$ $\left(1 \mathrm{H}, \mathrm{d},{ }^{3} J_{\mathrm{HH}}=7.6 \mathrm{~Hz}, \mathrm{Ar}-\mathrm{H}\right), 7.95\left(2 \mathrm{H}, \mathrm{d},{ }^{3} J_{\mathrm{HH}}=8.4 \mathrm{~Hz}, \mathrm{Ar}-\mathrm{H}\right), 7.48-$ $7.38(3 \mathrm{H}, \mathrm{m}, \mathrm{Ar}-\mathrm{H}), 7.15\left(2 \mathrm{H}, \mathrm{d},{ }^{3} \mathrm{~J}_{\mathrm{HH}}=8.0 \mathrm{~Hz}, \mathrm{Ar}-\mathrm{H}\right), 6.72(2 \mathrm{H}, \mathrm{d}$, $\left.{ }^{3} J_{\mathrm{HH}}=8.0 \mathrm{~Hz}, \mathrm{Ar}-\mathrm{H}\right), 5.50(1 \mathrm{H}, \mathrm{s}, \mathrm{CH}), 3.61\left(3 \mathrm{H}, \mathrm{s}, \mathrm{OCH}_{3}\right), 2.46(2 \mathrm{H}$, $\left.\mathrm{d},{ }^{2} J_{\mathrm{HH}}=17.6 \mathrm{~Hz}, \mathrm{CH}_{2} \mathrm{C}=\mathrm{O}\right), 2.36\left(1 \mathrm{H}, \mathrm{d},{ }^{2} J_{\mathrm{HH}}=16.4 \mathrm{~Hz}, \mathrm{CH}_{2}\right), 2.15$ $\left(1 \mathrm{H}, \mathrm{d},{ }^{2} J_{\mathrm{HH}}=16.4 \mathrm{~Hz}, \mathrm{CH}_{2}\right), 1.05\left(3 \mathrm{H}, \mathrm{s}, \mathrm{CH}_{3}\right), 0.90\left(3 \mathrm{H}, \mathrm{s}, \mathrm{CH}_{3}\right)$.

9,9-Dimethyl-12-(2-chlorophenyl)-8,9,10,12-tetrahydrobenzo [a]xanthene-11-one (4d). White solid. Mp: 178-180 ${ }^{\circ} \mathrm{C} . \bar{\nu}_{\max }$ $(\mathrm{KBr}) / \mathrm{cm}^{-1}$ : 3061 (=C-H), $2956(-\mathrm{C}-\mathrm{H}), 1670$ (C=O), 1622$1469(\mathrm{C}=\mathrm{C}), 1373\left(\mathrm{CH}_{3}\right.$, bending), 1300-1000 (C-O), $741(=\mathrm{C}-\mathrm{H}$ 
bending OOP of ortho disubstituted phenyl ring). ${ }^{1} \mathrm{H}$ NMR $\left(\right.$ DMSO- $\left._{6}\right) / \mathrm{ppm}: \delta_{\mathrm{H}}=8.12\left(1 \mathrm{H}, \mathrm{t},{ }^{3} J_{\mathrm{HH}}=8.0 \mathrm{~Hz}, \mathrm{Ar}-\mathrm{H}\right), 7.90$ $\left(2 \mathrm{H}, \mathrm{d},{ }^{3} \mathrm{~J}_{\mathrm{HH}}=8.0 \mathrm{~Hz}, \mathrm{Ar}-\mathrm{H}\right), 7.67-7.00(7 \mathrm{H}, \mathrm{m}, \mathrm{Ar}-\mathrm{H}), 5.78$ $(1 \mathrm{H}, \mathrm{s}, \mathrm{CH}), 2.68-2.67\left(4 \mathrm{H}, \mathrm{m}, \mathrm{CH}_{2} \mathrm{C}=\mathrm{O}\right.$ and $\left.\mathrm{CH}_{2}\right), 1.05(3 \mathrm{H}, \mathrm{s}$, $\left.\mathrm{CH}_{3}\right), 0.88\left(3 \mathrm{H}, \mathrm{s}, \mathrm{CH}_{3}\right)$.

4-(9,9-Dimethyl-11-oxo-8,10,11,12-tetrahydro-9H-benzo[ $[a]$ xanthene-12-yl)-benzaldehyde (4e). White yellow solid. Mp: 306-308 ${ }^{\circ} \mathrm{C}$. $\bar{\nu}_{\max }(\mathrm{KBr}) / \mathrm{cm}^{-1}: 3058(=\mathrm{C}-\mathrm{H}), 2958(-\mathrm{C}-\mathrm{H})$, $1670(\mathrm{C}=\mathrm{O}), 1595-1451(\mathrm{C}=\mathrm{C}), 1367\left(\mathrm{CH}_{3}\right.$, bending $), 1300-$ $1000(\mathrm{C}-\mathrm{O}) .{ }^{1} \mathrm{H}$ NMR $\left(\mathrm{DMSO}^{-} \mathrm{d}_{6}\right) / \mathrm{ppm}: \delta_{\mathrm{H}}=8.05-7.90(3 \mathrm{H}, \mathrm{m}$, $\mathrm{Ar}-\mathrm{H}), 7.60-7.45(3 \mathrm{H}, \mathrm{m}, \mathrm{Ar}-\mathrm{H}), 7.05(2 \mathrm{H}, \mathrm{s}, \mathrm{Ar}-\mathrm{H}), 5.58$ $(1 \mathrm{H}, \mathrm{s}, \mathrm{CH}), 2.54-2.00\left(4 \mathrm{H}, \mathrm{m}, \mathrm{CH}_{2} \mathrm{C}=\mathrm{O}\right.$ and $\left.\mathrm{CH}_{2}\right), 1.00(3 \mathrm{H}, \mathrm{s}$, $\left.\mathrm{CH}_{3}\right), 0.75\left(3 \mathrm{H}, \mathrm{s}, \mathrm{CH}_{3}\right)$.

9-(3-Nitrophenyl)-3,3,6,6-tetramethyl-3,4,5,6,7,9-hexahydro$1 H$-xanthene-1,8-(2H)-dione (5a). White solid. Mp: $171-173{ }^{\circ} \mathrm{C}$. $\bar{\nu}_{\max }(\mathrm{KBr}) / \mathrm{cm}^{-1}: 3063(=\mathrm{C}-\mathrm{H}), 2961(-\mathrm{C}-\mathrm{H}), 1662(\mathrm{C}=\mathrm{O}), 1623-$ $1429(\mathrm{C}=\mathrm{C}), 1355$ and $1529(\mathrm{~N}=\mathrm{O}), 1355\left(\mathrm{CH}_{3}\right.$, bending $), 1300-$ $1000(\mathrm{C}-\mathrm{O}) .{ }^{1} \mathrm{H}$ NMR $\left(\mathrm{DMSO}^{-} \mathrm{d}_{6}\right) / \mathrm{ppm}: \delta_{\mathrm{H}}=7.98-7.97(2 \mathrm{H}, \mathrm{m}$, $\mathrm{Ar}-\mathrm{H}), 7.64\left(1 \mathrm{H}, \mathrm{d},{ }^{3} J_{\mathrm{HH}}=8.0 \mathrm{~Hz}, \mathrm{Ar}-\mathrm{H}\right), 7.55\left(1 \mathrm{H}, \mathrm{t},{ }^{3} J_{\mathrm{HH}}=\right.$ $8.0 \mathrm{~Hz}, \mathrm{Ar}-\mathrm{H}), 4.65(1 \mathrm{H}, \mathrm{s}, \mathrm{CH}), 2.58-2.48\left(4 \mathrm{H}, \mathrm{m}, \mathrm{CH}_{2} \mathrm{C}=\mathrm{O}\right)$, $2.27\left(2 \mathrm{H}, \mathrm{d},{ }^{2} J_{\mathrm{HH}}=16.0 \mathrm{~Hz}, \mathrm{CH}_{2}\right), 2.10\left(2 \mathrm{H}, \mathrm{d},{ }^{2} J_{\mathrm{HH}}=16.0 \mathrm{~Hz}\right.$, $\left.\mathrm{CH}_{2}\right), 1.03\left(6 \mathrm{H}, \mathrm{s}, \mathrm{CH}_{3}\right), 0.89\left(6 \mathrm{H}, \mathrm{s}, \mathrm{CH}_{3}\right)$.

9-(2,4-Dichlorophenyl)-3,3,6,6-tetramethyl-3,4,5,6,7,9-hexahydro$1 H$-xanthene-1,8-(2H)-dione (5b). White solid. Mp: $245-247^{\circ} \mathrm{C} . \bar{\nu}_{\max }$ $(\mathrm{KBr}) / \mathrm{cm}^{-1}: 3070(=\mathrm{C}-\mathrm{H}), 2962(-\mathrm{C}-\mathrm{H}), 1661(\mathrm{C}=\mathrm{O}), 1623-1424$ $(\mathrm{C}=\mathrm{C}), 1359\left(\mathrm{CH}_{3}\right.$, bending), 1300-1000 (C-O). ${ }^{1} \mathrm{H}$ NMR (DMSO-d $\left.\mathrm{d}_{6}\right) /$ ppm: $\delta_{\mathrm{H}}=7.40(1 \mathrm{H}, \mathrm{s}, \mathrm{Ar}-\mathrm{H}), 7.28(2 \mathrm{H}, \mathrm{m}, \mathrm{Ar}-\mathrm{H}), 4.75(1 \mathrm{H}, \mathrm{s}, \mathrm{CH})$, $2.57\left(2 \mathrm{H}, \mathrm{d},{ }^{2} J_{\mathrm{HH}}=18.4 \mathrm{~Hz}, \mathrm{CH}_{2} \mathrm{C}=\mathrm{O}\right), 2.46\left(2 \mathrm{H}, \mathrm{d},{ }^{2} J_{\mathrm{HH}}=18.4 \mathrm{~Hz}\right.$, $\left.\mathrm{CH}_{2} \mathrm{C}=\mathrm{O}\right), 2.27\left(2 \mathrm{H}, \mathrm{d},{ }^{2} J_{\mathrm{HH}}=16.0 \mathrm{~Hz}, \mathrm{CH}_{2}\right), 2.05\left(2 \mathrm{H}, \mathrm{d},{ }^{2} J_{\mathrm{HH}}=\right.$ $\left.16.0 \mathrm{~Hz}, \mathrm{CH}_{2}\right), 1.02\left(6 \mathrm{H}, \mathrm{s}, \mathrm{CH}_{3}\right), 0.90\left(6 \mathrm{H}, \mathrm{s}, \mathrm{CH}_{3}\right)$.

9-(3-Methoxyphenyl)-3,3,6,6-tetramethyl-3,4,5,6,7,9-hexahydro- $1 H$-xanthene-1,8-(2H)-dione (5c). White solid. Mp: $240-$ $242{ }^{\circ} \mathrm{C} . \bar{\nu}_{\max }(\mathrm{KBr}) / \mathrm{cm}^{-1}: 3050(=\mathrm{C}-\mathrm{H}), 2958(-\mathrm{C}-\mathrm{H}), 1662(\mathrm{C}=$ O), 1592-1489 (C=C), $1370\left(\mathrm{CH}_{3}\right.$, bending), 1300-1000 (C-O), $824\left(=\mathrm{C}-\mathrm{H}\right.$ bending OOP of para disubstituted phenyl ring). ${ }^{1} \mathrm{H}$ NMR (DMSO-d $\left.{ }_{6}\right) / \mathrm{ppm}: \delta_{\mathrm{H}}=7.04\left(2 \mathrm{H}, \mathrm{d},{ }^{3} J_{\mathrm{HH}}=6.4 \mathrm{~Hz}, \mathrm{Ar}-\mathrm{H}\right)$, $6.75\left(2 \mathrm{H}, \mathrm{d},{ }^{3} J_{\mathrm{HH}}=7.2 \mathrm{~Hz}, \mathrm{Ar}-\mathrm{H}\right), 4.45(1 \mathrm{H}, \mathrm{s}, \mathrm{CH}), 3.66(3 \mathrm{H}, \mathrm{s}$, $\left.\mathrm{OCH}_{3}\right), 2.69-2.63\left(4 \mathrm{H}, \mathrm{m}, \mathrm{CH}_{2} \mathrm{C}=\mathrm{O}\right), 2.23\left(2 \mathrm{H}, \mathrm{d},{ }^{2} \mathrm{~J}_{\mathrm{HH}}=\right.$ $\left.16.0 \mathrm{~Hz}, \mathrm{CH}_{2}\right), 2.07\left(2 \mathrm{H}, \mathrm{d},{ }^{2} J_{\mathrm{HH}}=16.0 \mathrm{~Hz}, \mathrm{CH}_{2}\right), 1.02(6 \mathrm{H}, \mathrm{s}$, $\left.\mathrm{CH}_{3}\right), 0.88\left(6 \mathrm{H}, \mathrm{s}, \mathrm{CH}_{3}\right)$.

9-(4-Chlorophenyl)-3,3,6,6-tetramethyl-3,4,5,6,7,9-hexahydro- $1 \mathrm{H}$ xanthene-1,8-(2H)-dione (5d). White solid. Mp: $225-227{ }^{\circ} \mathrm{C} . \bar{\nu}_{\max }$ $(\mathrm{KBr}) / \mathrm{cm}^{-1}: 3050(=\mathrm{C}-\mathrm{H}), 2957(-\mathrm{C}-\mathrm{H}), 1663(\mathrm{C}=\mathrm{O}), 1594-1485$ $(\mathrm{C}=\mathrm{C}), 1364\left(\mathrm{CH}_{3}\right.$, bending), 1300-1000 (C-O), $742(=\mathrm{C}-\mathrm{H}$ bending OOP of ortho disubstituted phenyl ring). ${ }^{1} \mathrm{H}$ NMR (DMSO- $\left.\mathrm{d}_{6}\right) / \mathrm{ppm}$ : $\delta_{\mathrm{H}}=7.26-7.12(3 \mathrm{H}, \mathrm{m}, \mathrm{Ar}-\mathrm{H}), 7.09\left(1 \mathrm{H}, \mathrm{t},{ }^{3} J_{\mathrm{HH}}=5.6 \mathrm{~Hz}, \mathrm{Ar}-\mathrm{H}\right), 4.80$ $(1 \mathrm{H}, \mathrm{s}, \mathrm{CH}), 2.62\left(2 \mathrm{H}, \mathrm{d},{ }^{2} J_{\mathrm{HH}}=17.6 \mathrm{~Hz}, \mathrm{CH}_{2} \mathrm{C}=\mathrm{O}\right), 2.48\left(2 \mathrm{H}, \mathrm{d},{ }^{2} J_{\mathrm{HH}}\right.$ $\left.=17.6 \mathrm{~Hz}, \mathrm{CH}_{2} \mathrm{C}=\mathrm{O}\right), 2.24\left(2 \mathrm{H}, \mathrm{d},{ }^{2} J_{\mathrm{HH}}=16.4 \mathrm{~Hz}, \mathrm{CH}_{2}\right), 2.02(2 \mathrm{H}, \mathrm{d}$, $\left.{ }^{2} J_{\mathrm{HH}}=16.4 \mathrm{~Hz}, \mathrm{CH}_{2}\right), 1.02\left(6 \mathrm{H}, \mathrm{s}, \mathrm{CH}_{3}\right), 0.90\left(6 \mathrm{H}, \mathrm{s}, \mathrm{CH}_{3}\right)$.

4,4'-Benzilidine-bis[3,3,6,6-tetramethyl-3,4,5,6,7,9-hexahydro-1H-xanthene-1,8-(2H)-dione] (5e). White solid. Mp: 228-230 ${ }^{\circ} \mathrm{C} . \bar{\nu}_{\max }(\mathrm{KBr}) / \mathrm{cm}^{-1}: 3049(=\mathrm{C}-\mathrm{H}), 2962(-\mathrm{C}-\mathrm{H})$, $1610(\mathrm{C}=\mathrm{O}), 1584-1400(\mathrm{C}=\mathrm{C}), 1389\left(\mathrm{CH}_{3}\right.$, bending $), 1300-$ $1000(\mathrm{C}-\mathrm{O}), 828(=\mathrm{C}-\mathrm{H}$ bending OOP of para disubstituted phenyl ring). ${ }^{1} \mathrm{H}$ NMR (DMSO- $\left.\mathrm{d}_{6}\right) / \mathrm{ppm}: \delta_{\mathrm{H}}=7.40(4 \mathrm{H}, \mathrm{s}, \mathrm{Ar}-$ $\mathrm{H}), 4.75(2 \mathrm{H}, \mathrm{s}, \mathrm{CH}), 2.77-2.49\left(8 \mathrm{H}, \mathrm{m}, \mathrm{CH}_{2} \mathrm{C}=\mathrm{O}\right), 2.26(4 \mathrm{H}$, $\left.\mathrm{d},{ }^{2} J_{\mathrm{HH}}=16.0 \mathrm{~Hz}, \mathrm{CH}_{2}\right), 2.06\left(4 \mathrm{H}, \mathrm{d},{ }^{2} J_{\mathrm{HH}}=16.0 \mathrm{~Hz}, \mathrm{CH}_{2}\right)$, $1.02\left(12 \mathrm{H}, \mathrm{s}, \mathrm{CH}_{3}\right), 0.88\left(12 \mathrm{H}, \mathrm{s}, \mathrm{CH}_{3}\right)$.

12-(4-Hydroxyphenyl)-8,10-dimethyl-8,10-dihydro-9H-benzo [5,6]chromene[2,3,d]pyrimidine-9,11-(10H)-dione (7a). Cream solid. Mp: $286-288^{\circ} \mathrm{C} . \bar{\nu}_{\max }(\mathrm{KBr}) / \mathrm{cm}^{-1}: 3206(\mathrm{O}-\mathrm{H}), 3053$ (=C$\mathrm{H}), 2926(-\mathrm{C}-\mathrm{H}), 1669(\mathrm{C}=\mathrm{O}), 1541-1417(\mathrm{C}=\mathrm{C}), 1356\left(\mathrm{CH}_{3}\right.$, bending), $1300-1000(\mathrm{C}-\mathrm{O}), 855(=\mathrm{C}-\mathrm{H}$ bending $\mathrm{OOP}$ of para disubstituted phenyl ring). ${ }^{1} \mathrm{H}$ NMR (DMSO- $\left.\mathrm{d}_{6}\right) / \mathrm{ppm}: \delta_{\mathrm{H}}=8.90$ $(1 \mathrm{H}, \mathrm{s}, \mathrm{OH}), 8.30\left(2 \mathrm{H}, \mathrm{d},{ }^{3} \mathrm{JHH}_{\mathrm{HH}}=8.0 \mathrm{~Hz}, \mathrm{Ar}-\mathrm{H}\right), 8.03-7.85(3 \mathrm{H}, \mathrm{m}$, $\mathrm{Ar}-\mathrm{H}), 7.53-7.43(3 \mathrm{H}, \mathrm{m}, \mathrm{Ar}-\mathrm{H}), 6.95\left(2 \mathrm{H}, \mathrm{d},{ }^{3} \mathrm{~J}_{\mathrm{HH}}=8.0 \mathrm{~Hz}, \mathrm{Ar}-\right.$ $\mathrm{H}), 5.98(1 \mathrm{H}, \mathrm{s}, \mathrm{CH}), 3.33\left(3 \mathrm{H}, \mathrm{s}, \mathrm{CH}_{3}\right), 3.19\left(3 \mathrm{H}, \mathrm{s}, \mathrm{CH}_{3}\right)$.

12-(2,4-Dichlorophenyl)-8,10-dimethyl-8,10-dihydro-9Hbenzo[5,6]chromene $[2,3, d]$ pyrimidine-9,11-(10H)-dione (7b). White solid. Mp: $263-265{ }^{\circ} \mathrm{C} . \bar{\nu}_{\max }(\mathrm{KBr}) / \mathrm{cm}^{-1}: 3058(=\mathrm{C}-\mathrm{H})$, $2952(-\mathrm{C}-\mathrm{H}), 1707(\mathrm{C}=\mathrm{O}), 1661-1456(\mathrm{C}=\mathrm{C}), 1355\left(\mathrm{CH}_{3}\right.$, bending), $1300-1000(\mathrm{C}-\mathrm{O}) .{ }^{1} \mathrm{H}$ NMR (DMSO- $\left.\mathrm{d}_{6}\right) / \mathrm{ppm}: \delta_{\mathrm{H}}=$ 7.55-7.42 (4H, m, Ar-H), 7.31 (1H, s, Ar-H), $7.12\left(1 \mathrm{H}, \mathrm{d},{ }^{3} J_{\mathrm{HH}}\right.$ $=9.6 \mathrm{~Hz}, \mathrm{Ar}-\mathrm{H}), 6.90-6.65(3 \mathrm{H}, \mathrm{m}, \mathrm{Ar}-\mathrm{H}), 5.77(1 \mathrm{H}, \mathrm{s}, \mathrm{CH})$, $3.50\left(3 \mathrm{H}, \mathrm{s}, \mathrm{CH}_{3}\right), 3.20\left(3 \mathrm{H}, \mathrm{s}, \mathrm{CH}_{3}\right)$.

12-(4-Nitrophenyl)-8,10-dimethyl-8,10-dihydro-9H-benzo $[5,6]$ chromene $[2,3, d]$ pyrimidine-9,11-(10H)-dione (7c). Cream solid. Mp: $286-288{ }^{\circ} \mathrm{C} . \bar{\nu}_{\max }(\mathrm{KBr}) / \mathrm{cm}^{-1}: 3090$ (=C$\mathrm{H}), 2850(-\mathrm{C}-\mathrm{H}), 1753(\mathrm{C}=\mathrm{O}), 1674-1441(\mathrm{C}=\mathrm{C}), 1575$ and $1342(\mathrm{~N}=\mathrm{O}), 1342\left(\mathrm{CH}_{3}\right.$, bending), 1300-1000 $(\mathrm{C}-\mathrm{O}), 836$ (= $\mathrm{C}-\mathrm{H}$ bending OOP of para disubstituted phenyl ring). ${ }^{1} \mathrm{H}$ NMR (DMSO- $\left.\mathrm{d}_{6}\right) / \mathrm{ppm}: \delta_{\mathrm{H}}=8.05-7.90(5 \mathrm{H}, \mathrm{m}, \mathrm{Ar}-\mathrm{H}), 7.68-$ $7.63(2 \mathrm{H}, \mathrm{m}, \mathrm{Ar}-\mathrm{H}), 7.55-7.44(3 \mathrm{H}, \mathrm{m}, \mathrm{Ar}-\mathrm{H}), 5.83(1 \mathrm{H}, \mathrm{s}$, $\mathrm{CH}), 3.49\left(3 \mathrm{H}, \mathrm{s}, \mathrm{CH}_{3}\right), 3.13\left(3 \mathrm{H}, \mathrm{s}, \mathrm{CH}_{3}\right)$.

12-(4-Methylphenyl)-8,10-dimethyl-8,10-dihydro-9H-benzo[5,6] chromene[2,3,d]pyrimidine-9,11-(10H)-dione (7d). White solid. Mp: 195-197 ${ }^{\circ} \mathrm{C} . \bar{\nu}_{\max }(\mathrm{KBr}) / \mathrm{cm}^{-1}$ : 3015 (=C-H), $2952(-\mathrm{C}-\mathrm{H}), 1709$ (C= O), 1630-1452 ( $\mathrm{C}=\mathrm{C}), 1399\left(\mathrm{CH}_{3}\right.$, bending), 1300-1000 (C-O), 808 ( $=\mathrm{C}-\mathrm{H}$ bending OOP of para disubstituted phenyl ring). ${ }^{1} \mathrm{H}$ NMR (DMSO- $\left.\mathrm{d}_{6}\right) / \mathrm{ppm}: \delta_{\mathrm{H}}=8.03-7.90(3 \mathrm{H}, \mathrm{m}, \mathrm{Ar}-\mathrm{H}), 7.59\left(1 \mathrm{H}, \mathrm{t},{ }^{3} J_{\mathrm{HH}}=\right.$ $8.0 \mathrm{~Hz}, \mathrm{Ar}-\mathrm{H}), 7.56-7.48(2 \mathrm{H}, \mathrm{m}, \mathrm{Ar}-\mathrm{H}), 7.19\left(2 \mathrm{H}, \mathrm{d},{ }^{3} \mathrm{~J}_{\mathrm{HH}}=6.8 \mathrm{~Hz}\right.$, $\mathrm{Ar}-\mathrm{H}), 6.97\left(2 \mathrm{H}, \mathrm{d},{ }^{3} J_{\mathrm{HH}}=6.8 \mathrm{~Hz}, \mathrm{Ar}-\mathrm{H}\right), 5.60(1 \mathrm{H}, \mathrm{s}, \mathrm{CH}), 3.49$ $\left(3 \mathrm{H}, \mathrm{s}, \mathrm{CH}_{3}\right), 3.14\left(3 \mathrm{H}, \mathrm{s}, \mathrm{CH}_{3}\right), 2.12\left(3 \mathrm{H}, \mathrm{s}, \mathrm{CH}_{3}\right)$.

12-(4-Methoxyphenyl)-8,10-dimethyl-8,10-dihydro-9H-benzo $[5,6]$ chromene[2,3,d]pyrimidine-9,11-(10H)-dione (7e). Yellow solid. Mp: $292-294^{\circ} \mathrm{C} . \bar{\nu}_{\max }(\mathrm{KBr}) / \mathrm{cm}^{-1}: 3103$ (=C-H), $2955(-\mathrm{C}-$ $\mathrm{H}), 1737(\mathrm{C}=\mathrm{O}), 1665-1432(\mathrm{C}=\mathrm{C}), 1362\left(\mathrm{CH}_{3}\right.$, bending $), 1300-$ $1000(\mathrm{C}-\mathrm{O}), 1267$ and $1084(\mathrm{Ar}-\mathrm{C}-\mathrm{O}), 849(=\mathrm{C}-\mathrm{H}$ bending OOP of para disubstituted phenyl ring). ${ }^{1} \mathrm{H}$ NMR (DMSO- $\left.\mathrm{d}_{6}\right) / \mathrm{ppm}: \delta_{\mathrm{H}}$ $=8.05-7.67(3 \mathrm{H}, \mathrm{m}, \mathrm{Ar}-\mathrm{H}), 7.55-7.44(4 \mathrm{H}, \mathrm{m}, \mathrm{Ar}-\mathrm{H}), 7.20(2 \mathrm{H}, \mathrm{d}$, $\left.{ }^{3} J_{\mathrm{HH}}=7.2 \mathrm{~Hz}, \mathrm{Ar}-\mathrm{H}\right), 6.67\left(2 \mathrm{H}, \mathrm{d},{ }^{3} J_{\mathrm{HH}}=7.2 \mathrm{~Hz}, \mathrm{Ar}-\mathrm{H}\right), 5.60$ $(1 \mathrm{H}, \mathrm{s}, \mathrm{CH}), 3.49\left(3 \mathrm{H}, \mathrm{s}, \mathrm{CH}_{3}\right), 3.35\left(3 \mathrm{H}, \mathrm{s}, \mathrm{OCH}_{3}\right), 3.21(3 \mathrm{H}, \mathrm{s}$, $\left.\mathrm{CH}_{3}\right)$.

12-(2-Hydroxyphenyl)-8,10-dimethyl-8,10-dihydro-9H-benzo [5,6]chromene[2,3,d]pyrimidine-9,11-(10H)-dione (7f). Cream solid. Mp: $288-290^{\circ} \mathrm{C} . \bar{\nu}_{\max }(\mathrm{KBr}) / \mathrm{cm}^{-1}: 3300(\mathrm{O}-\mathrm{H}), 3052$ (=CH), $2962(-\mathrm{C}-\mathrm{H}), 1700(\mathrm{C}=\mathrm{O}), 1584-1400(\mathrm{C}=\mathrm{C}), 1379\left(\mathrm{CH}_{3}\right.$, bending), $1300-1000(\mathrm{C}-\mathrm{O}), 759(=\mathrm{C}-\mathrm{H}$ bending OOP of ortho disubstituted phenyl ring). ${ }^{1} \mathrm{H}$ NMR (DMSO- $\mathrm{d}_{6}$ )/ppm: $\delta_{\mathrm{H}}=8.75$ (1H, s, OH), 7.78-7.52 (3H, m, Ar-H), 7.32-6.85 (7H, m, Ar-H), $5.83(1 \mathrm{H}, \mathrm{s}, \mathrm{CH}), 3.49\left(3 \mathrm{H}, \mathrm{s}, \mathrm{CH}_{3}\right), 3.13\left(3 \mathrm{H}, \mathrm{s}, \mathrm{CH}_{3}\right)$.

12-(3-Methoxyphenyl)-8,10-dimethyl-8,10-dihydro-9H-benzo $[5,6]$ chromene $[2,3, d]$ pyrimidine-9,11-(10H)-dione (7g). Yellow 
solid. Mp: $283-285^{\circ} \mathrm{C} . \bar{\nu}_{\max }(\mathrm{KBr}) / \mathrm{cm}^{-1}$ : 3027 (=C-H), $2959(-\mathrm{C}-$ $\mathrm{H}), 1671(\mathrm{C}=\mathrm{O}), 1595-1451(\mathrm{C}=\mathrm{C}), 1368\left(\mathrm{CH}_{3}\right.$, bending $), 1300-$ $1000(\mathrm{C}-\mathrm{O}) .{ }^{1} \mathrm{H}$ NMR $\left(\mathrm{DMSO}_{6}\right) / \mathrm{ppm}: \delta_{\mathrm{H}}=7.65\left(2 \mathrm{H}, \mathrm{t},{ }^{3} J_{\mathrm{HH}}=\right.$ $7.6 \mathrm{~Hz}, \mathrm{Ar}-\mathrm{H}), 7.55-7.42(5 \mathrm{H}, \mathrm{m}, \mathrm{Ar}-\mathrm{H}), 7.29-7.07$ (3H, m, Ar-H), $5.87(1 \mathrm{H}, \mathrm{s}, \mathrm{CH}), 3.65\left(3 \mathrm{H}, \mathrm{s}, \mathrm{OCH}_{3}\right), 3.56\left(3 \mathrm{H}, \mathrm{s}, \mathrm{CH}_{3}\right), 3.12$ $\left(3 \mathrm{H}, \mathrm{s}, \mathrm{CH}_{3}\right)$.

\section{Conclusions}

In this study, perlite nanoparticles was prepared and modified with Lewis acidic ionic liquid (perlite NPs@IL/ $/ \mathrm{rCl}_{4}$ ) and characterized with FTIR, XRD, SEM, EDX and TGA techniques. We presented a new efficient and environmental friendly pathway for one pot synthesis of xanthene and naphthopyranopyrimidine derivatives via multicomponent reactions using perlite

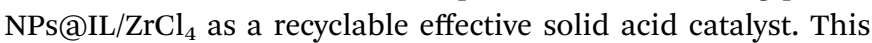
simple procedure is solvent free and it's easy and clean work up, high yield of products and reusability of catalyst as well as low cost and very little amounts of catalyst (0.005 g, $0.4 \mathrm{~mol} \%)$, make this method considerable for the synthesis of other organic compounds.

\section{Conflicts of interest}

There are no conflicts to declare.

\section{Acknowledgements}

We are thankful from University of Kashan for supporting this study by Grant No. 784946 .

\section{References}

1 M. El-Brashy, M. E. Metwally and F. A. El-Sepai, IL Farmaco, 2004, 59, 809.

2 K. Chibale, M. Visser, D. V. Schalkwyk, P. J. Smith, A. Saravanamuthu and A. H. Fairlamb, Tetrahedron, 2003, 59, 2289.

3 B. B. Bhowmik and P. Ganguly, Spectrochim. Acta, Part A, 2005, 61, 1997.

4 M. Ahmad, T. A. King, D. K. Ko, B. H. Cha and J. Lee, J. Phys. D: Appl. Phys., 2002, 35, 1473.

5 C. G. Knight and T. Stephens, Biochem. J., 1989, 258, 683.

6 F. A. Eid, A. H. F. Abd El-Waheb, G. A. M. El-Hag Ali and M. M. Khafagy, Acta Pharm., 2004, 54, 13.

7 A. H. Bedair, N. A. El-Hady, M. S. A. El-Latif, A. H. Fakery and A. M. El-Agrody, IL Farmaco, 2000, 55, 708.

8 O. Bruno, C. Brullo, S. Schenone, F. Bondavalli, A. Ranise and M. Tognolini, Bioorg. Med. Chem., 2006, 14, 121.

9 K. C. Joshi, R. Jain, K. Sharma, S. K. Bhattacharya and R. K. Goel, J. Indian Chem. Soc., 1988, 115, 202.

10 O. Bruno, C. Brullo, S. Schenone, A. Ranise, F. Bondavalli, E. Barocelli, M. Tognolini, F. Magnanini and V. Ballabeni, IL Farmaco, 2002, 57, 753.

11 O. Bruno, C. Brullo, S. Schenone, F. Bondavalli, A. Ranise, M. Tognolini, V. Ballabeni and E. Barocelli, Bioorg. Med. Chem., 2004, 12, 553.
12 F. Chabchoub, M. Messaâd, H. Ben Mansour, L. Ghdira and M. Salem, Eur. J. Med. Chem., 2007, 42, 715.

13 M. M. Khafagy, A. H. F. Abd El-Wahab, F. A. Eid and A. M. ElAgrody, IL Farmaco, 2002, 57, 715.

14 M. Messaâd, F. Chabchoub and M. Salem, Heterocycl. Commun., 2005, 9, 401.

15 O. Kodama, H. Ichikawa, T. Akatsuka, V. Santisopasri, A. Kato and Y. Hayashi, J. Nat. Prod., 1993, 56, 292.

16 J. V. Mdhav, B. S. Kuram and B. Rajitha, ARKIVOC, 2008, ii, 204.

17 B. Das, B. Ravikanth, R. Ramu, K. Laxminarayana and B. v. Rao, J. Mol. Catal. A: Chem., 2006, 255, 74.

18 P. Liu, H. Jian-Wu, S. J. Liang, G. L. Liang, J. Y. Wang and Z.-H. Zhang, Monatsh. Chem., 2016, 147, 801.

19 B. Karami, K. Eskandari, Z. Zare and S. Gholipour, Chem. Heterocycl. Compd., 2014, 49, 1715.

20 J. Safaei-Ghomi and M. A. Ghasemzadeh, Chin. Chem. Lett., 2012, 23, 1225.

21 H. R. Shaterian, M. Ghashang and N. Mir, ARKIVOC, 2007, xv, 1.

22 B. Rajitha, B. S. Kumar, B. Y. T. Reddy and P. N. Reddy, Tetrahedron Lett., 2005, 46, 8691.

23 E. Mirhadi, A. Ramazani, M. Rouhani and S. Woo Joo, Chemija, 2013, 24, 320.

24 A. Saini, S. Kumar and J. S. Sandhu, Synlett, 2006, 12, 1928. 25 M. Seyyedhamzeh, P. Mirzaei and A. Bazgir, Dyes Pigm., 2008, 76, 836.

26 S. Kantevari, M. V. Chary, A. P. R. Das, S. V. N. Vuppalapati and N. Lingaiah, Catal. Commun., 2008, 9, 1575.

27 T. Ohishi, T. Kojima, T. Matsuoka, M. Shiro and H. Kotsuki, Tetrahedron Lett., 2001, 42, 2493.

28 R. Rao Chinta, V. Harikrishna, V. Kumar Tulam, P. S. Mainkar and P. K. Dubey, Asian J. Chem., 2016, 28, 899.

29 X. J. Sun, J. F. Zhou and P. S. Zhao, J. Heterocycl. Chem., 2011, 48, 1347.

30 S. S. Jalde, H. V. Chavan, L. K. Adsul, V. D. Dhakane and B. P. Bandgar, Synth. React. Inorg., Met.-Org., Nano-Met. Chem., 2014, 44, 623.

31 H. R. Shaterian, K. Azizi and N. Fahimi, Res. Chem. Intermed., 2014, 40, 1403.

32 M. M. Lakouraj, Z. Fallah, M. Tajbakhsh and V. Hasantabar, Caspian Journal of Chemistry, 2014, 3, 45.

33 H. Naeimi and Z. S. Nazifi, J. Chin. Chem. Soc., 2013, 60, 1113. 34 A. R. Hajipour, Y. Ghayeb, N. Sheikhan and A. E. Ruoho, Synlett, 2010, 5, 0741.

35 K. Gong, D. Fang, H.-L. Wang, X.-L. Zhou and Z.-L. Liu, Dyes Pigm., 2009, 80, 30.

36 A. Zhu, S. Bai, W. Jin, R. Liu, L. Li, Y. Zhao and J. Wang, RSC Adv., 2014, 4, 36031.

37 J. Yang, J. Yang, T. Zhu, P. Wang and D. Fang, Monatsh. Chem., 2013, 144, 1705.

38 P. Kumari, V. Yathindranath and S. M. S. Chauhan, Synth. Commun., 2008, 38, 637.

39 M. Arifuzzaman and H. S. Kim, Constr. Build. Mater., 2017, 141, 201.

40 M. Singh and M. Garg, Constr. Build. Mater., 1991, 5, 75. 
41 M. Arifuzzaman and H. S. Kim, Constr. Build. Mater., 2017, 148, 321.

42 D. Shastri and H. S. Kim, Constr. Build. Mater., 2014, 60, 1.

43 S. F. Torabi, K. Khajeh, S. Ghasempur, N. Ghaemi and S. O. R. Siadat, J. Biotechnol., 2007, 131, 111.

44 A. Rostami-Vartooni, M. Nasrollahzadeh, M. Alizadeh and W. F. Hölderich, J. Alloys Compd., 2016, 680, 309.

45 B. Maleki, M. Gholizadeh and Z. Sepehr, Bull. Korean Chem. Soc., 2011, 32, 1697.

46 S. C. Azimi, Iran. J. Catal., 2015, 5, 41.

47 G. C. Nandi, S. Samai and M. S. Singh, Synlett, 2010, 7, 1133. 48 M. Mohaqeq, J. Safaei-Ghomi, H. Shahbazi-Alavi and R. Teymuri, Polycyclic Aromat. Compd., 2017, 37, 52.

49 P. J. Das and J. Das, RSC Adv., 2015, 5, 11745.

50 N. Ghaffari Khaligh, Res. Chem. Intermed., 2018, 44, 4045.

51 N. G. Chandra, S. Subhasis, R. Kumar and M. S. Singh, Tetrahedron, 2009, 65, 7129.

52 N. Aayesha, Asian J. Chem., 2013, 25, 7535.

53 K. Niknam and M. Damya, J. Chin. Chem. Soc., 2009, 56, 659. 54 A. N. Dadhania, V. K. Patel and D. K. Raval, C. R. Chim., 2012, 15, 378 .

55 H. Eshghi, M. Rahimizadeh, M. Eftekhar and M. Bakavoli, Kinet. Catal., 2014, 55, 428.
56 S. M. Sajadi, M. Maham and B. O. Ahmad, Lett. Org. Chem., 2014, 11, 317.

57 O. Soleimani and A. Hosseinian, J. Chem. Res., 2018, 42, 337. 58 A. Rahmati, Chin. Chem. Lett., 2010, 21, 761.

59 A. Zare, A. R. Moosavi-Zare, M. Merajoddin, M. A. Zolfigol, T. Hekmat-Zadeh, A. Hasaninejad, A. Khazaei, M. Mokhlesi, V. Khakyzadeh, F. Derakhshan-Panah, M. H. Beyzavi, E. Rostami, A. Arghoon and R. Roohandeh, J. Mol. Liq., 2012, 167, 69.

60 K. Rad-Moghadam and S. C. Azimi, J. Mol. Catal. A: Chem., 2012, 363-364, 465.

61 S. S. Sajadikhah, RSC Adv., 2015, 5, 28038.

62 S. S. Jalde, H. V. Chavan, L. K. Adsul, V. D. Dhakane and B. P. Bandgar, Synth. React. Inorg. Met.-Org. Chem., 2014, 44, 623.

63 K. Praveen Kumar, S. Satyanarayana, P. Lakshmi Reddy, G. Narasimhulu, N. Ravirala and B. V. Subba Reddy, Tetrahedron Lett., 2012, 53, 1738.

64 L. Wu, X. Wang, L. Yang and F. Yan, Asian J. Chem., 2010, 22, 6178.

65 P. Kumar, W. Vermeiren, J. P. Dath and W. F. Hölderich, Appl. Catal., A, 2006, 304, 131. 